\title{
Patterns of habitat segregation among large fishes in a Venezuelan floodplain river
}

\author{
Craig A. Layman*,** and Kirk O. Winemiller*
}

\begin{abstract}
Distribution and abundance of large fishes $(\mathrm{SL}>100 \mathrm{~mm})$ in the río Cinaruco, a floodplain river in the Venezuelan llanos, were examined by gill net sampling in four habitat types: sand banks, backwater creeks, floodplain lagoons, and river channel. Sampling was standardized using nets $(25 \mathrm{~m} \mathrm{x} 2 \mathrm{~m})$ of three mesh sizes set for $24-\mathrm{h}$ periods. Based on data from $>10,000$ hours of gill netting over three years, there were significant differences in assemblage composition among the four habitats. Pair-wise comparisons suggested differences in assemblage composition between all pairs of habitats except creeks and lagoons. Differences in assemblage composition likely arose from speciesspecific habitat affinities. For example, 21 taxa were collected from both creeks and lagoons, but not from sand banks or the main river channel; each of these 21 taxa were associated with particular features characteristic of creeks and lagoons (e.g. abundant detritus). Assemblage structure also could be influenced by predation or other biological interactions, but mechanistic experiments are needed to evaluate this hypothesis. Assemblage composition was highly variable within all habitat types, likely the result of spatial and temporal heterogeneity associated with seasonal hydrology. Long distance migrations by prochilodontids and other taxa contributed to higher CPUE during the rising-water period of May 2002. Data from this study will provide a baseline to assess changes in the abundance and distribution of large-bodied fishes in response to increasing impacts from illegal commercial fishing in this region.
\end{abstract}

A distribuição e abundância de grandes peixes ( $\mathrm{SL}>100 \mathrm{~mm}$ ) no rio Cinaruco, um rio com uma planície inundação nos llanos da Venezuela, foram examinadas através de amostragens por redes de espera em quatro habitats: bancos de areia, riachos, lagoas da planície de inundação e o canal do rio. As amostragens foram padronizadas usando-se redes de espera $(25 \mathrm{~m} \times 2 \mathrm{~m})$ de três tamanhos de malha expostas por períodos de 24 horas. Baseando-se em dados de mais de 10.000 horas de exposição de redes, coletados por três anos, foram verificadas diferenças significativas na composição da assembléia entre os quatro habitats. Comparações pareadas sugeriram que diferenças na composição da assembléia provavelmente se devem às afinidades espécie-habitat. Por exemplo, 21 taxa foram coletados em riachos e lagoas, mas não em bancos de areia ou no canal principal do rio, sendo que cada um destes 21 taxa foi associado a características particulares dos riachos e das lagoas (ex. detrito abundante). A estrutura da assembléia também poderia ser influenciada por predação ou outras interações biológicas, mas são necessários experimentos para avaliar esta hipótese. A composição da assembléia foi altamente variável dentro de todos os tipos de habitats, provavelmente devido à heterogeneidade espacial e temporal associada com a sazonalidade na hidrologia. As grandes migrações realizadas por prochilodontídeos e outros taxa contribuíram para uma maior captura por unidade de esforço (CPUE) durante o período de subida das águas, em maio de 2002. Os dados deste estudo fornecerão a base para a verificação de mudanças na abundância e distribuição dos peixes de grande porte em resposta aos crescentes impactos causados pela pesca comercial ilegal nesta região.

Key words: assemblage structure, habitat affinity, lagoon, migration, predation.

*Section of Ecology and Evolutionary Biology, Department of Wildlife and Fisheries Sciences, 210 Nagle Hall, Texas A\&M University, College Station, TX 77843-2258 USA. email (CAL): cal1634@yahoo.com; (KOW): k-winemiller@tamu.edu

**Current address: Department of Ecology and Evolutionary Biology, Yale University, PO Box 208106, New Haven, CT $06520-8106$ USA. 


\section{Introduction}

Neotropical freshwater fish communities may be stochastically assembled (Lowe-McConnell, 1987; Goulding et al., 1988; Jepsen, 1997; Saint-Paul et al., 2000) or non-randomly structured according to habitat selection and/or biological interactions (Winemiller, 1996; Jepsen et al., 1997; Rodríguez \& Lewis, 1997; Arrington \& Winemiller, 2003; Petry et al., 2003; Layman $\&$ Winemiller, 2004; Arrington et al., in press). These alternative views are largely derived from patterns viewed from different spatial and temporal scales (see Levin, 1992). For example, there are five spatial scales at which fish communities may exhibit non-random structure: (1) among drainage basins, (2) among habitats (e.g., between river channel and floodplain lagoons), (3) among sites for a given habitat type (e.g., among lagoons that vary in transparency), (4) among micro-habitats within a habitat (e.g., sand bank vs. rocky structure in one lagoon), and (5) according to fine-scale abiotic variation (e.g., water velocity, water column position, or substrate) within a habitat.

Studies in tropical freshwaters typically examine fish assemblage structure among drainage basins (Agostinho et al., 2000; Saint-Paul et al., 2000), or at one of the latter three scales identified above (Winemiller, 1989, 1990; Rodríguez \& Lewis 1997; Tejerina-Garro et al., 1998; Winemiller \& Jepsen, 1998; Súarez et al., 2001, Arrington \& Winemiller, 2003; Arrington et al., in press). In this study, assemblages of large-bodied fishes in the río Cinaruco, Venezuela, were examined, during the dry season and early rising-water period, among four landscapescale habitat types: sand banks, backwater creeks, floodplain lagoons, and main river channel. Peacock cichlids (Cichla spp.) have been shown to partition habitats, with Cichla intermedia (Machado-Allison) restricted largely to the main river channel, and Cichla orinocensis (Humboldt) to floodplain lagoons, in the río Cinaruco (Jepsen et al., 1997; Winemiller et al., 1997). This study further evaluates potential habitat associations of large-bodied fish species in the río Cinaruco using data from $>10,000$ hours of gill net sampling over a three-year period.

\section{Materials and Methods}

\section{Study Site}

The río Cinaruco is a tropical floodplain tributary of the Orinoco River that drains the llanos (savanna) of southern Venezuela $\left(6^{\circ} 32^{\prime} \mathrm{N}, 67^{\circ} 24^{\prime} \mathrm{W}\right)$. The Cinaruco is an oligotrophic, moderate blackwater river with high levels of dissolved organic carbon and low pH. Hydrology is strongly seasonal, with water levels fluctuating more than $5 \mathrm{~m}$ annually. In the wet season (May to October) the riparian forest is flooded, and dispersal of organisms is extensive (Welcomme, 1979; Lowe-McConnell, 1987). From November to January, rapidly falling water results in higher fish densities and intensification of many biotic interactions (e.g. predation) during the dry season (January-April) (Winemiller, 1990; Rodríguez \& Lewis, 1994, 1997; Winemiller \& Jepsen, 1998; Layman \& Winemiller, 2004). Maximum width of the main channel during the dry season is $40-200 \mathrm{~m}$. The river supports a diverse fish community ( $>280$ species), with taxa representing a wide range of ecological attributes and life history strategies (Jepsen et al., 1997; Winemiller et al., 1997; Arrington \& Winemiller, 2003; Winemiller \& Jepsen 2003; Arrington et al., in press). A detailed description of the Río Cinaruco can be found in Jepsen (1999).

Four habitats are common in the río Cinaruco: sand banks, backwater creeks, floodplain lagoons, and the river channel. During the dry season (January to April), the main river channel contains long (up to $2 \mathrm{~km}$ ), broad, sand banks that constitute a large proportion of river shoreline. Sand banks slope gradually, with depths in most areas $<1.5 \mathrm{~m}$. Meandering creeks fringed by dense gallery forest drain the floodplain and flow into backwater areas of lagoons. During the dry season, creeks have low water velocity $\left(0-0.2 \mathrm{~m} \mathrm{sec}^{-1}\right)$ and maximum depths of $\sim 3 \mathrm{~m}$ (see Hoeinghaus et al., 2003a). Lagoons ( 1-30 km²) are connected to the river by varying degrees. In the dry season, most lagoons become partially isolated water bodies, as connections between lagoons and the river channel become restricted (width of connections at lagoon mouths $\sim 1-100 \mathrm{~m}$ ). Maximum lagoon depths are $\sim 7 \mathrm{~m}$ in the dry season, but in most areas lagoon dpeths are $<2.5 \mathrm{~m}$. Both creeks and lagoons have heterogeneous habitat features including sand, leaf litter, cut banks, partially submerged overhanging vegetation, submerged branches and tree falls, and reaches with accumulated detritus. The main river channel is 3-7 m deep in the dry season. Water velocity in the channel varies substantially both seasonally and spatially.

\section{Sampling Methodology}

Sampling was conducted from January 2 to June 5 in three years $(2001,2002,2003)$. The objective was to describe assemblage composition among the four habitat types, but not to compare micro-habitats within each habitat. Thus, sampling locations were haphazardly chosen within habitats, and no location was sampled more than once. Multiple sites from 10 different sand banks, 4 creeks, 10 lagoons, and a $12-\mathrm{km}$ stretch of the main river channel were sampled during the course of the study. Sampling dates were chosen at random in each year, but with all habitat types sampled throughout sampling periods. Samples in January-April were considered to be dry season, and May and June in the rising water period.

Fishes were sampled with three monofilament gill nets (25 m x $2 \mathrm{~m})$, each with a different mesh size $(2.5,3.75$, and 5 $\mathrm{cm})$. Nets of each mesh size were simultaneously deployed with $\sim 5 \mathrm{~m}$ between nets. In creeks, lagoons, and river channel, nets were secured by the float-line to submerged or overhanging vegetation near the bank, and the nets stretched taut. Nets on sand banks were secured to $1.8 \mathrm{~m}$ metal posts that were driven into the sand. In most cases, nets were set so most of their length was in contact with the substrate. Sampling effort was standardized by deploying nets for 24 hours at each site. Nets were checked at dawn, mid-day, and dusk, and all individuals were measured (standard length, SL, in millimeters and weight in grams) and identified to 
species. Problematic species were identified to genus and assigned a numeric species identifier (Table 1). Voucher specimens were archived in the Museo de Ciencias Naturales at the Universidad de Los Llanos Occidentales in Guanare, Venezuela.

In gill net sampling, some piscivores that feed on fishes caught in nets (e.g. piranha) may be over-estimated due to high net encounter rates, whereas sedentary species may be underestimated. Gill net samples do not provide an unbiased description of assemblages, but allow for relative abundance comparisons among sampling dates or locations when based on a standardized sampling protocol (Hickford \& Schiel, 1995; Kurkilahti \& Rask, 1996; Miranda et al., 2000; Saint-Paul et al., 2000; Silvano et al., 2000; Tejerina-Garro \& De Merona, 2001; Hoeinghaus et al., 2003a). Abundance was recorded as catch per unit effort (CPUE), the number of individuals collected from a gill net sample (3 gill nets at a given site over a 24 hour period). Species density was the number of species collected in each standardized sample (following Gotelli \& Colwell, 2001).

\section{Statistical Analyses}

To best assess assemblage structure and dynamics, both aggregate (e.g., CPUE and species density) and composition measures should be used in analyses (Micheli et al., 1999). Comparisons among mean aggregate values were conducted using non-parametric Kruskal-Wallis ANOVA and MannWhitney Rank Sum Test. Multi-dimensional scaling (MDS) was used to compare fish assemblage similarity/dissimilarity based on species relative abundances. MDS constructs a 2-dimensional ordination in a manner that best represents relationships among samples in a similarity matrix (Field et al., 1982; Clarke \& Warwick, 2001). In ordination plots, the relative distance between points reflects the dissimilarity of species composition in those samples. Similarity matrices were calculated using the Bray-Curtis similarity index (Bray \& Curtis, 1957). Analysis of similarities (ANOSIM; Clarke \& Warwick, 1994), a non-parametric analog of MANOVA, was used to test for differences in species composition among habitat categories. When ANOSIM revealed significant differences, similarity percentage analysis (SIMPER) (Clarke \& Warwick, 1994) was performed to identify species accounting for differences.

\section{Results}

In 150 samples (10,800 gill net hours), 4,140 individuals of 72 species from 13 families were collected. The three most commonly collected species, accounting for $33 \%$ of all individuals, were the piscivores Hydrolycus armatus (Jardine and Schomburgk) and Serrasalmus manueli (Fernández-Yépez \& Ramírez) and the algivore/detritivore Semaprochilodus kneri (Pellegrin) (Table I). Other common fish (>3.0\% of all individuals collected) were ctenolucid piscivores Boulengerella spp., omnivorous Leporinus spp., omnivorous Triportheus albus (Cope), herbivorous Myleus spp., and the benthic insectivore Hassar ucayalensis (Fowler). Average CPUE and species density were significantly different among habitat types (Fig. 1; Kruskal-Wallis, both $P<0.001$ ). Creeks had highest mean CPUE $(46.9 \pm 43.1)$ and species density (13.5 \pm 7.8). Sand banks had lowest mean CPUE (17.8 \pm 23.6$)$, and river channel sites the lowest mean species density (5.1 \pm $3.0)$. The range of individuals collected in a sample was 1146 , and species density range was 1-30.

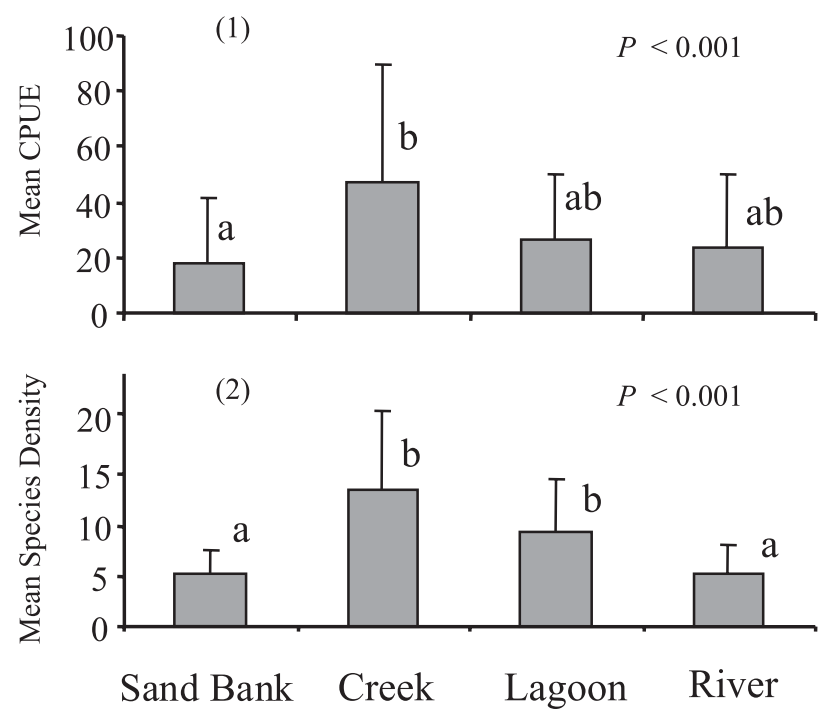

Fig. 1. Mean (1) CPUE (catch per unit effort) and (2) species density in the four habitat types. Error bars are 1 S.D. Letters next to habitat types represent results of Dunn's post-hoc test for differences in mean values between each habitat pair.

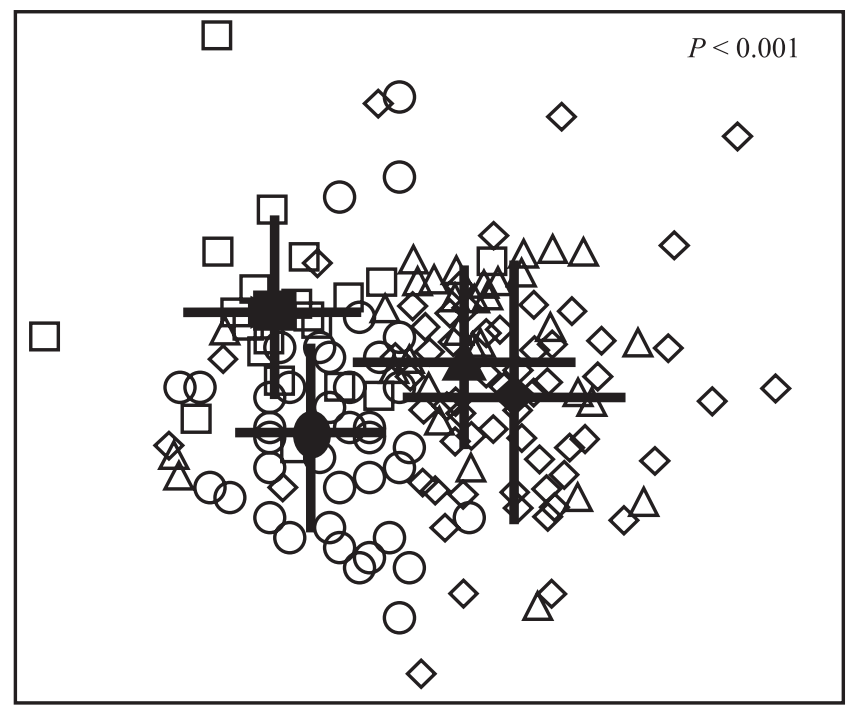

Fig. 2. Multi-dimensional scaling (MDS) ordination depicting the relative similarity of assemblage composition. Each open symbol on the graph represents one sample (i.e. 3 gill nets set for 24 hours), and the closed symbols are sample means for each of the four habitat types. Error bars are 1 S.D. Channel $=$ squares; sand bank $=$ circles; creek $=$ triangles; lagoon $=$ diamonds. 
Table 1. Percentage of the total number individuals represented by each species and the frequency which each was collected in the 150 samples. Habitat abbreviations are: $\mathrm{C}-$ Creek; L - Lagoon; R - River Channel; S - Sand Bank.

\begin{tabular}{|c|c|c|c|}
\hline & $\begin{array}{c}\% \text { of Total } \\
\text { Fishes }\end{array}$ & $\begin{array}{c}\text { Frequency of } \\
\text { Occurrence }\end{array}$ & Habitats \\
\hline Hydrolycus armatus & $12.7 \%$ & $50.6 \%$ & C L R S \\
\hline Semaprochilodus kneri & $10.3 \%$ & $56.5 \%$ & C L R S \\
\hline Serrasalmus manueli & $9.9 \%$ & $64.3 \%$ & C L R S \\
\hline Boulengerella lucius & $6.2 \%$ & $44.8 \%$ & C L R S \\
\hline Leporinus sp. 1 & $5.7 \%$ & $37.7 \%$ & C L R S \\
\hline Boulengerella cuvieri & $4.0 \%$ & $27.9 \%$ & C L R S \\
\hline Hassar ucayalensis & $3.6 \%$ & $20.8 \%$ & C L R S \\
\hline Triportheus albus & $3.1 \%$ & $24.0 \%$ & C L R S \\
\hline Myleus spp. & $3.0 \%$ & $24.0 \%$ & C L R S \\
\hline Brycon falcatus & $2.7 \%$ & $6.5 \%$ & C L R S \\
\hline Laemolyta taeniatus & $2.7 \%$ & $24.7 \%$ & C L R S \\
\hline Hemiodus unimaculatus & $2.3 \%$ & $22.1 \%$ & C L R S \\
\hline Chalceus macrolepidotus & $2.2 \%$ & $14.3 \%$ & C L \\
\hline Geophagus spp. & $2.1 \%$ & $26.6 \%$ & C L R S \\
\hline Plagioscion squamosissimus & $1.9 \%$ & $19.5 \%$ & C L R S \\
\hline Cichla temensis & $1.8 \%$ & $26.0 \%$ & C L R S \\
\hline Curimata incompta & $1.6 \%$ & $15.6 \%$ & $\mathrm{CLS}$ \\
\hline Metynnis hypsauchen & $1.6 \%$ & $13.6 \%$ & C L \\
\hline Pristobrycon striolatus & $1.6 \%$ & $18.8 \%$ & C L \\
\hline Cynodon gibbus & $1.4 \%$ & $9.1 \%$ & C L R \\
\hline Myleus schomberkyi & $1.4 \%$ & $16.2 \%$ & $\mathrm{CL} \mathrm{R} \mathrm{S}$ \\
\hline Leporinus sp. 2 & $1.2 \%$ & $11.0 \%$ & $\mathrm{R} \mathrm{C}$ \\
\hline Lorichariichthys brunneus & $1.1 \%$ & $13.6 \%$ & C L R \\
\hline Serrasalmus rhombeus & $1.1 \%$ & $15.6 \%$ & C L R \\
\hline Leporinus sp. 3 & $1.0 \%$ & $15.6 \%$ & C L R \\
\hline Hemiodus argenteus & $1.0 \%$ & $11.7 \%$ & C L S \\
\hline Pellona castelnaeana & $0.8 \%$ & $12.3 \%$ & C L R S \\
\hline Pseudoplatystoma fasciatum & $0.8 \%$ & $13.6 \%$ & C L S \\
\hline Holias malabaricus & $0.8 \%$ & $9.7 \%$ & C L \\
\hline Semaprochilodus laticeps & $0.7 \%$ & $5.2 \%$ & C L \\
\hline Serrasalmus altuvei & $0.7 \%$ & $13.6 \%$ & C L S \\
\hline Curimata vittata & $0.7 \%$ & $6.5 \%$ & C L \\
\hline Acestrorhynchus falcirostris & $0.6 \%$ & $11.0 \%$ & $\mathrm{C} \mathrm{L}$ \\
\hline Hemiodis immaculatus & $0.6 \%$ & $9.1 \%$ & C L R S \\
\hline Anodus orinocensis & $0.5 \%$ & $5.8 \%$ & $\mathrm{C} \mathrm{L}$ \\
\hline Satanoperca daemon & $0.5 \%$ & $7.8 \%$ & C L S \\
\hline Boulengerella maculata & $0.4 \%$ & $7.8 \%$ & C L S \\
\hline Crenicichla o-lugubris & $0.4 \%$ & $7.8 \%$ & C L R \\
\hline Oxydoras niger & $0.4 \%$ & $7.1 \%$ & $\mathrm{LS}$ \\
\hline Ageneiosus brevifilis & $0.3 \%$ & $5.8 \%$ & $\mathrm{C} \mathrm{L}$ \\
\hline Mylossoma aureus & $0.3 \%$ & $5.8 \%$ & C L R S \\
\hline Platynematichthys notatus & $0.3 \%$ & $3.9 \%$ & C L R S \\
\hline Serrasalmus medinae & $0.3 \%$ & $5.8 \%$ & C L R \\
\hline Argonectes longiceps & $0.3 \%$ & $4.5 \%$ & C R S \\
\hline Cichla intermedia & $0.3 \%$ & $5.2 \%$ & L R S \\
\hline Cichla orinocensis & $0.2 \%$ & $6.5 \%$ & C L \\
\hline Raphiodon vulpinnis & $0.2 \%$ & $3.9 \%$ & C L S \\
\hline Bivibranchia fowleri & $0.2 \%$ & $5.8 \%$ & C L R S \\
\hline Hypostomus argus & $0.2 \%$ & $5.8 \%$ & C L \\
\hline Leporinus sp. 4 & $0.2 \%$ & $2.6 \%$ & C R S \\
\hline Brycon sp. & $0.2 \%$ & $4.5 \%$ & $\mathrm{CLS}$ \\
\hline Heroes sp. & $0.2 \%$ & $1.9 \%$ & C L \\
\hline Agoniates anchovia & $0.1 \%$ & $3.2 \%$ & CL S \\
\hline Hoplarchus psitticus & $0.1 \%$ & $1.9 \%$ & L R \\
\hline Pachypops furcraeus & $0.1 \%$ & $3.2 \%$ & $\mathrm{CS}$ \\
\hline Platydoras costatus & $0.1 \%$ & $1.9 \%$ & C L \\
\hline Pristobrycon calmoni & $0.1 \%$ & $2.6 \%$ & C L \\
\hline Leiarus marmoratus & $0.1 \%$ & $3.2 \%$ & $\mathrm{~L}$ \\
\hline Piaractus brachypomus & $0.1 \%$ & $1.9 \%$ & $\bar{L}$ \\
\hline Psectrogaster ciliata & $0.1 \%$ & $2.6 \%$ & $\mathrm{CL}$ \\
\hline Pigocentrus cariba & $0.1 \%$ & $1.9 \%$ & $\mathrm{~L}$ \\
\hline Catoprion mento & $0.1 \%$ & $1.3 \%$ & $\mathrm{~L}$ \\
\hline Serrasalmus elongatus & $0.1 \%$ & $0.6 \%$ & $\mathrm{~L}$ \\
\hline Cochliodon plecostomoides & $0.1 \%$ & $1.9 \%$ & C L \\
\hline Glyptoperichthys gibbiceps & $0.1 \%$ & $1.9 \%$ & C L \\
\hline Pseudoplatystoma tigrinum & $0.1 \%$ & $1.9 \%$ & C L \\
\hline Auchenipterichthys longimanus & $0.0 \%$ & $1.3 \%$ & C L \\
\hline Rhamdia sp. & $0.0 \%$ & $1.3 \%$ & C L \\
\hline Bryconops caudomaculatus & $0.0 \%$ & $0.6 \%$ & $\mathrm{~L}$ \\
\hline Dekesaria scaphyrhyncha & $0.0 \%$ & $0.6 \%$ & $\mathrm{C}$ \\
\hline Sorubim lima & $0.0 \%$ & $0.6 \%$ & $\mathrm{~L}$ \\
\hline Trachycorystes trachycorystes & $0.0 \%$ & $0.6 \%$ & $\mathrm{C}$ \\
\hline
\end{tabular}

Assemblage composition was significantly different among habitats (ANOSIM, $P<0.001$; Fig. 2). Pair-wise comparisons revealed significant differences between all habitat pairs (ANOSIM, all $P<0.001$ ) except between creeks and lagoons $(P=0.13)$. Hydrolycus armatus and $S$. kneri were more commonly collected in creeks and lagoons, and $S$. manueli and Serrasalmus rhombeus (L.) most commonly in river channels. Boulengerella spp. revealed habitat partitioning, with Boulengerella cuvieri (Agassiz) more common on main channel sand banks and Boulengerella lucius (Cuvier) common in creeks and lagoons. Benthic invertivores, such as H. ucayalensis and Geophagus spp., were collected most often in lagoons. Triportheus albus and Leporinus sp. 1 were most commonly collected in creeks (except for Leporinus sp. 1 during one week in May, see below). There were no species collected on either sand banks or in the river channel that were not also collected in either a lagoon or creek sample. In contrast, 21 species were collected in both creeks and lagoons, but in neither of the other two habitats.

Average CPUE was higher during the dry season (33.1 \pm $31.9)$ relative to the rising water period ( $22.3 \pm 26.0$; MannWhitney $P=0.04)$. CPUE of the four most commonly collected species (Table 1) was higher during the dry season than rising-water period. Assemblage composition was significantly different within both dry- and rising-water periods (ANOSIM, dry $P<0.001$, rising $P=0.011$ ), with MDS ordinations suggesting slightly more structured communities (i.e. higher similarity in composition within habitat types) for the dry season samples. Assemblage composition did not differ among years (ANOSIM, $P=0.57$ ).

Highest CPUE recorded for a lagoon sample $(\mathrm{n}=119)$, highest for a channel sample $(\mathrm{n}=114)$, and second highest for a sand bank sample $(n=40)$ occurred during a one week period, May 19-26, 2002. The mean CPUE of all samples taken during this week $(44.5 \pm 34.8)$ was significantly higher than the mean CPUE for the remaining samples $(26.2 \pm 28.0$; MannWhitney, $P=0.021)$. These samples were characterized by higher CPUE of Leporinus sp. 1 (CPUE all samples $=1.1$, CPUE May 19-26 = 7.3), Myleus spp. $(0.4,2.7)$ and Semaprochilodus kneri $(2.9,4.2)$. The mean CPUE $(13.4 \pm$ 19.9) of samples taken after this week (May 27-June 5) was significantly lower than the average CPUE of remaining samples $(28.6 \pm 29.0$, Mann-Whitney $P=0.021)$.

\section{Discussion}

Although fish assemblage composition was extremely variable among samples within each habitat type, assemblage structure tended to differ between habitat categories. In pairwise comparisons, assemblage composition of habitat types (except creeks and lagoons) was found to be significantly different, suggesting some level of structure at the landscape scale. Two questions stem from these data: (1) what is the mechanism(s) producing assemblage structure at the landscape scale?, and (2) what factors contribute to high variability in fish assemblages within habitats? 
Patterns observed are most likely driven by species-specific habitat affinities, manifest in variation in relative abundance of common species and the presence/absence of rarer species in certain habitat types. For example, Serrasalmus spp. had higher mean CPUE at deeper sites, and thus were more frequently collected in the main river channel. Alternatively, Boulengerella spp. rarely were collected in deep water sites, but dominated sand bank assemblages. Relative abundances of Serrasalmus and Boulengerella species accounted for much of the difference between assemblages on sand banks and the river channel. Relatively high mean CPUE of Semaprochilodus kneri and Hydrolycus armatus in creeks and lagoons was the main factor differentiating assemblages of these two habitats from sand bank and river channel assemblages. Detritivorous S. kneri may inhabit creeks and lagoons to exploit large deposits of particulate organic matter and relatively high benthic primary production (as indexed by chlorophyll $a$ concentrations, Winemiller et al., in prep.) in these habitats.

Most of the 21 species collected exclusively from creeks and lagoons can be classified into one of three trophic categories: (1) piscivores (e.g. Ageneiosus brevifilis Valenciennes, Cichla orinocensis, Hoplias malabaricus Bloch), (2) species that consume allochthonous terrestrial plant material such as flowers and seeds (Chalceus macrolepidotus Cuvier, Metynnis hypsauchen Müller \& Troschel), and (3) algivore/detritivores (Hypostomus argus Fowler, Psectrocaster ciliata Müller \& Troschel, Semaprochilodus laticeps Steindachner). These species may prefer creeks and lagoons because these habitats contain submerged structure that attracts small prey fishes, abundant overhanging vegetation that supplies flowers and seeds, and benthic algal and detrital resources. During the dry season, creeks are essentially lentic extensions of lagoons, and it is not surprisingly that creeks and lagoons had similar fish assemblages.

Fish assemblage structure at (and within) the landscape scale also could be influenced by species interactions. For example, some of the most common prey species (Hemiodus immaculatus Kner, Laemolyta taeniatus Lütken, Leporinus sp.1, Semaprochilodus kneri) of large piscivores (e.g. Cichla spp.) had highest mean CPUE in creeks. These prey taxa were especially abundant in the upper, shallower portions of creeks where large piscivores are rare. This is consistent with prey distribution patterns driven by predator avoidance, as experimentally demonstrated for prey species on sand bank habitats in the river channel (Layman \& Winemiller, 2004). Further experiments are needed to test if predator avoidance and/or the availability of food resources determines distribution of prey species among (and within) habitats.

Fish assemblage composition within habitat types was variable due to high spatial and temporal heterogeneity that is characteristic of floodplain rivers. Physical habitat characteristics varied widely within each of the four habitat categories. Lagoons have backwater areas with substrates dominated by coarse particulate organic matter, as well as broad, sandy flats. Hence, a lagoon sample from a sandy area should more closely resemble a river sand bank sample than an average lagoon sample. Similarly, samples from deep-water lagoon locations may be similar to samples from the river channel. Sampling sites were chosen essentially at random, therefore, significant differences in assemblage composition among habitats, despite heterogeneity of sites within habitat types, suggest characteristic fish assemblages in the four habitat types.

Floodplain rivers are dynamic (Welcomme, 1979; Hamilton \& Lewis, 1987; Lewis et al., 2000), and fish assemblages may differ substantially among seasons (Saint-Paul et al., 2000; Arrington, 2002). The peak in mean CPUE during a single week in May 2002 likely was the result of the "ribazón", an annual migration of fishes during rising- and falling-water periods (Lilyestrom, 1983; Barbarino Duque et al., 1998). Species with higher than average CPUE during this week (Leporinus spp. Myleus spp., and Semaprochilodus kneri) are major components of the ribazón in other floodplain rivers (Goulding, 1980; Lowe-McConnell, 1987). For example, $S$. kneri undergoes long distance migrations to spawn in the productive Orinoco floodplain (Winemiller \& Jepsen, 1998, 2003), and the high CPUE in late May likely reflect this seasonal movement. Mean CPUE of samples was significantly lower following this week, likely the result of rapidly increasing water levels (thus flooding the riparian forest, providing additional aquatic habitat for fish dispersal) and emmigration of certain species in the ribazón.

Some large-bodied species which are common in the river were not effectively sampled by the gill netting methodology. For example, data from hook-and-line sampling suggests that Cichla are among the most common large-bodied fishes in the river (Jepsen et al., 1997; Winemiller et al., 1997). Cichla are diurnally active and visually acute, and can probably avoid gill nets. Sedentary species, such as loricariid catfishes, also are less likely to encounter gill nets. In speciose aquatic systems, multiple sampling methodologies are needed to adequately assess fish abundance and distribution. Nevertheless, standardized CPUE information provided by gill net sampling allows comparisons among sites, especially for susceptible species, and also provides baseline data that can be used to assess shifts in assemblage composition over time.

In recent years, illegal commercial netting has increased in the río Cinaruco (Hoeinghaus et al., 2003b). Netters target large-bodied taxa, including the two most common species in gill net sampling, $H$. armatus and $S$. kneri. These species have important ecological functions and population reductions could result in altered ecological dynamics. For example, the algivorous/detritivorous $S$. kneri is a major prey of large piscivores (Jepsen, 1997; Layman et al., 2005), and by feeding low in the food web, piscivores increase efficiency of energy conversion. Compressed food webs are characteristic of Neotropical floodplain rivers (Lewis et al., 2001; Layman et al., 2005; Layman et al., in press), and may explain why fish production is so high in these systems. Consequently, declining S. kneri populations could result in reduced piscivore populations. These gill net surveys provide a baseline for monitoring long-term changes in fish stocks in response to commercial fishing, as well as a basis for future conservation initiatives. 


\section{Acknowledgements}

Edgar Pelaéz, Jim Marzoula, Carol Marzoula, and Glenn Webb provided logistical support through the Cinaruco River Fishing Club and Tour Apure. Don Taphorn at UNELLEZ provided logistical support and helped with fish identification. Jeremy Walther, David Hoeinghaus, Carmen Montaña, and others assisted with field collections. Alexis Medina and Pablo Medina are given special thanks for their help throughout this study. Fish collections were made with fishing permits \#0439 and \#0486 issued by the Servicio Autonomo de los Recursos Pesqueros y Acuicolas of Venezuela. Danielle Peretti translated the abstract. This work was funded by a U.S. Environmental Protection Agency Science to Achieve Results Graduate Fellowship, Texas A \& M Regents and Tom Slick Fellowships, William 'Bill' Baab Conservation Fellowship, and National Science Foundation grant DEB-0089834.

\section{Literature Cited}

Agostinho, A. A., S. M. Thomaz, C. V. Minte-Vera \& K. O. Winemiller. 2000. Biodiversity in the High Paraná River Floodplain. Pp. 89-118. In: Gopal, B., W. J. Junk \& J. A. Davis (Eds.). Biodiversity in wetlands: assessment, function, and conservation. Leiden, Backhuys.

Arrington, D. A., K. O. Winemiller \& C. A. Layman. In press. Community assembly at the patch scale in a species-rich tropical river. Oecologia.

Arrington, D. A. \& K. O. Winemiller. 2003. Diel changeover in sand-beach fish assemblages in a Neotropical floodplain river. Environmental Biology of Fishes, 63:442-459.

Barbarino Duque, A., D. C. Taphorn \& K. O. Winemiller. 1998. Ecology of the coporo, Prochilodus mariae (Characiformes, Prochilodontidae), and status of annual migrations in western Venezuela. Environmental Biology of Fishes, 53:33-46.

Bray, J. R. \& J. C. Curtis. 1957. An ordination of the upland forest communities of southern Wisconsin. Ecological Monographs, 27:325-349.

Clarke, K. R. \& R. M. Warwick. 2001. Change in marine communities: an approach to statistical analysis and interpretation, 2nd edition. Plymouth: PRIMER-E Ltd.

Clarke, K. R. \& W. M. Warwick. 1994. Similarity-based testing for community pattern: the 2-way layout with no replication. Marine Biology, 118:167-176.

Field, J. G., K. R. Clarke \& R. M. Warwick. 1982. A practical strategy for analyzing multi-species distribution patterns. Marine Ecology Progress Series, 8:37-53.

Gotelli, N. J. \& R. K. Colwell. 2001. Quantifying biodiversity: procedures and pitfalls in the measurement and comparison of species richness. Ecology Letters, 4:379-391.

Goulding, M. 1980. The Fishes and the Forest. Berkeley, University of California Press.

Goulding, M., M. L. Carvalho \& E. G. Ferreira. 1988. Rio Negro: Rich Life in Poor Water. The Hague, SPB Academic.
Hamilton, S. K. \& W. M. J. Lewis. 1987. Causes of seasonality in the chemistry of a lake of the Orinoco River floodplain, Venezuela. Limnology and Oceanography, 32: 1277-1290.

Hickford, M. J. H. \& D. R. Schiel. 1995. Catch vs. count: effects of gill-netting on reef fish populations in southern New Zealand. Journal of Experimental Marine Biology and Ecology, 188: 215-232.

Hoeinghaus, D. J., C. A. Layman, D. A. Arrington \& K. O. Winemiller. 2003a. Spatiotemporal variation in fish assemblage structure in tropical floodplain creeks. Environmental Biology of Fishes, 67:379-387.

Hoeinghaus, D. J., C. A. Layman, D. A. Arrington \& K. O. Winemiller. 2003b. Movement of Cichla spp. (Cichlidae) in a Venezuelan floodplain river. Neotropical Ichthyology, 1:121-126.

Jepsen, D. B. 1997. Fish species diversity in sand bank habitats of a Neotropical river. Environmental Biology of Fishes, 49:449-460.

Jepsen, D. B. 1999. Analysis of trophic pathways in freshwater ecosystems using stable isotope signatures. Unpublished Ph.D. Thesis, Texas A \& M University, USA.

Jepsen, D. B., K. O. Winemiller \& D. C. Taphorn. 1997. Temporal patterns of resource partitioning among Cichla species in a Venezuelan blackwater river. Journal of Fish Biology, 51:1085-1108.

Kurkilahti, M. \& M. Rask. 1996. A comparitive study of the usefulness and catchability of multimesh gill nets and gill net series in sampling of perch (Perca fluviatilis) and roach (Rutilus rutilus). Fisheries Research, 27:243-260.

Layman, C.A, Winemiller, K.O., Arrington, D.A. \& D. B. Jepsen. In press. Body size and trophic position in a diverse tropical food web. Ecology.

Layman, C.A., K. O. Winemiller \& D. A. Arrington. 2005. Describing the structure and function of a Neotropical river food web using stable isotope ratios, stomach contents, and functional experiments. In: J. C. Moore, P. De Ruiter \& V. Wolters (Eds.). Dynamic Food Webs: Multispecies Assemblages, Ecosystem Development, and Environmental Change. Elsevier/Academic Press.

Layman, C. A. \& K. O. Winemiller. 2004. Size-based prey response to piscivore exclusion in a Neotropical river. Ecology, 85:1311-1320.

Levin, S. A. 1992. The problem of pattern and scale in ecology. Ecology, 73:1943-1967.

Lewis, W. M. Jr., S. K. Hamilton, M. A. Lasi, M. A. Rodríguez $\&$ J. F. Saunders III. 2000. Ecological determinism on the Orinoco floodplain. BioScience, 50:681-692.

Lewis, W. M. Jr., S. K. Hamilton, M. A. Rodríguez, J. F. Saunders III \& M. A. Lasi. 2001. Food web analysis of the Orinoco floodplain based on production estimates and stable isotope data. Journal of the North American Benthological Society, 20: 241-254.

Lilyestrom, C. G. 1983. Aspectos de la biología del coporo (Prochilodus mariae). Revista de Ciéncia y Tecnología 
UNELLEZ, 1:5-11.

Lowe-McConnell, R. H. 1987. Ecological Studies in Tropical Fish Communities. London, Cambridge University Press.

Micheli, F., K. L. Cottingham, J. Bascompte, O. N. Bjørnstad, G. L. Eckert, J. M. Fischer, T. H. Keitt, B. E. Kendall, J. L. Klug \& J. A. Rusak. 1999. The dual nature of community variability. Oikos, 85:161-169.

Miranda, L. E., A. A. Agostinho \& L. C. Gomes. 2000. Appraisal of the selective properties of gill nets and implications for yield and value of the fisheries at the Itaipu Reservoir, Brazil-Paraguay. Fisheries Research, 45:105-116.

Petry, P., P. B. Bayley \& D. F. Markle. 2003. Relationships between fish assemblages, macrophytes and environmental gradients in the Amazon River floodplain. Journal of Fish Biology, 63:547-579.

Rodríguez, M. A. \& W. M. Lewis Jr. 1994. Regulation and stability in fish assemblages of Neotropical floodplain lakes. Oecologia, 99:166-180.

Rodríguez, M. A. \& W. M. Lewis Jr. 1997. Structure of fish assemblages along environmental gradients in floodplain lakes of the Orinoco River. Ecological Monographs, 67:109-128.

Saint-Paul, U., J. Zuanon, M. A. Villacorta Correa, M. García, N. N. Fabré, U. Berger \& Junk, W. J. 2000. Fish communities in central Amazonian white- and blackwater floodplains. Environmental Biology of Fishes, 57:235-250.

Silvano, R. A. M., B. D. do Amaral \& O. T. Oyakawa. 2000. Spatial and temporal patterns of diversity and distribution of the Upper Juruá River fish community (Brazilian Amazon). Environmental Biology of Fishes, 57:25-35.

Súarez, Y. R., M. J. Petrere \& A. C. Catella. 2001. Factors determining the structure of fish communities in Patanal lagoons (MS, Brazil). Fisheries Management and Ecology, 8:173-186

Tejerina-Garro, F. L. \& B. De Merona. 2001. Gill net sampling standardisation in large rivers of French Guiana (South America). Bulletin Francais De La Peche Et De La Piscicultura, 357-360:227-240.

Tejerina-Garro, F. L., R. Fortín \& M. A. Rodríguez. 1998. Fish community structure in relation to environmental variation in floodplain lakes of the Araguaia River, Amazon Basin. Environmental Biology of Fishes, 51:399-410.

Welcomme, R. L. 1979. Fisheries Ecology of Floodplain Rivers. New York, Longman.

Winemiller, K. O. 1989. Ontogenetic diet shifts and resource partitioning among piscivorous fishes in the Venezuelan llanos. Environmental Biology of Fishes, 26: 177-199.

Winemiller, K. O. 1990. Spatial and temporal variation in tropical fish trophic networks. Ecological Monographs, 60:331-367.

Winemiller, K. O. 1996. Factors driving temporal and spatial variation in aquatic floodplain food webs. Pp. 298-312. In: Polis G. A. \& K. O. Winemiller (Eds.). Food Webs: Integration of Patterns and Processes. New York, Chapman \& Hall.

Winemiller, K. O. \& D. B. Jepsen. 1998. Effects of seasonality and fish movement on tropical river food webs. Journal of Fish Biology, 53 Supplement A:267-296.

Winemiller, K. O. \& D. B. Jepsen. 2003. Migratory neotropical fish subsidize food webs of oligotrophic blackwater rivers. Pps. 115-231. In: Food webs at the landscape level (Polis, G. A., M. E. Power \& G. Huxel (Eds.). Chicago, University of Chicago Press.

Winemiller, K. O., D. C. Taphorn \& A. Barbarino-Duque. 1997. Ecology of Cichla (Cichlidae) in two blackwater rivers of southern Venezuela. Copeia, 1997:690-696.

Received December 2004 Accepted February 2005 